\title{
Hagyományos és modern kulturális határok
}

\author{
Zala megye nyilvános élete az 1860-as években
}

Előadásomban Zala megye nyilvános életének egy rövid korszakát fogom megvizsgálni: az 1848/49-es forradalmat követő időszaknak, a neoabszolutizmusnak a második felét, az 1860-as éveket. Ezt a korszakot a történetírás hagyományosan - a megelőző reformkorhoz, illetve a rákövetô polgári korhoz képest - kevésbé részesíti figyelemben. Márpedig a neoabszolutizmus, részben éppen átmenetiségénél fogva, érdekes problémákat és kérdéseket vet fel a hazai társadalomfejlődés és kulturális átalakulás, más szavakkal a rendi társadalom bomlása, a polgárosodás kapcsán. A kérdés a legtömörebben a következőképp fogalmazható meg: vajon 1848at követôen folytonosságról vagy megszakítottságról beszélhetünk a magyar társadalom fejlődésében? Előadásomban a társadalom kulturális tagolódásának vizsgálatán keresztül szeretném ezt a kérdést érinteni.

A nyilvános életet (amely most a legtágabb értelemben az emberek egymás elôtt, egymással folytatott interakciókban folyó társas életét jelenti) kulturális határvonalak tagolták. Mégpedig úgy - ez lényegi állításom -, hogy részben érvényben maradtak még a rendi korszakból örökölt hagyományos kulturális választóvonalak, másrészt azonban - a megelőző polgári és a folyamatban lévő gazdasági forradalom hatására - új, vagyis modern választóvonalak is kialakultak, amelyek alapvetốn más elvek szerint alakultak, mint a korábbiak.

Nem érintem a nyilvános élet (ha tetszik nyilvánosság) minden formáját (erre az idő sem lenne elegendô), hanem csak azokhoz a területeihez fordulok, amelyek, mivel kívül estek a törvényi szabályozáson, nem intézményesültek. Az intézményes formába szerveződő nyilvánosság, vagyis az egyesületi élet, a sajtó vagy éppen a középszintú politizálás (a megyegyúlések) világa mindenkor - és ebben az idôszakban különösen - ki van téve a politikai hatalom ellenőrzésének és beleszólásának. Ezzel szemben az általam nem intézményesített nyilvánosságnak nevezett társadalmi szféra többet képes megőrizni spontaneitásából, ezáltal - várakozásaim szerint - hívebben tükrözi a társadalom (változásának) belsố folyamatait.

A 19. század közepén Zala megye népességét a következőképp lehet leírni. A hagyományosan nagyarányú nemességéról ismert megye zömében római katolikus lakosságú volt, csak a nagyobb városokban (Nagykanizsán, Zalaegerszegen, kisebb mértékben Keszthelyen, Sümegen) élt számottevő arányú izraelita népesség. A lakosság fő bevételi forrása szerint agrárnépesség volt, illetve, ugyancsak a városokban, nagyobb kézmúves, kisiparos csoportok is éltek. Ez a tömör leírás önmagában alkalmas arra, hogy a „,hagyományos” kulturális határvonalakra rávilágítson. A társadalom hagyományos kulturális tagolódását ugyanis a rendi állás, a vallás, illetve 
a fó bevételi forrás jelölte ki. Ezek a határvonalak - hagyományosan - nemcsak a társadalomban betöltött pozíciót, hanem ezzel egyidejúleg a nyilvános életben elfoglalható helyet is meghatározták.

\section{Hagyományos kulturális határvonalak}

A vallás, alapvetô identitásformáló funkciója mellett, jelentős szerepet töltött be a társas élet alakításban is, miután elsődleges keretet biztosított az egy vallási csoporthoz tartozók találkozásához és közös időtöltéséhez. A vizsgált korszakban Zala megye felekezeti megoszlása úgy alakult, hogy a döntően római katolikus megyében (1857-70 között kb. 90\%) a második legnagyobb vallási csoport az izraelitáké volt (kb. 4\%), és nagyjából ugyanekkora részt adott a két nagy protestáns felekezet is (nagyjából fele-fele részben, bár a reformátusok aránya valamivel magasabb volt az evangélikusokénál). A felekezeti csoportok tagjai szocializációjuk során alapvetően azonos erkölcsi normákat sajátítottak el, ebből fakadóan közös értékeket vallottak, mentalitásuk alapja ebben az értelemben azonos volt. Mégis a rendi helyzetből fakadó társadalmi presztízs erős határvonalakat húzott a csoport tagjai közé, ami a mindennapi vallásgyakorlás során (például a templomi ülésrendben vagy a körmenetekben elfoglalt helyben) a résztvevők számára világosan megmutatkozott. Természetesen a csoporton belüli választóvonalaknál jóval erősebb volt a csoportok között húzódó határvonal, ami ugyancsak megmutatkozott a felekezeti nyilvános életben is. A helyi sajtó kuriózumként említi azt az 1863-as esetet, amikor az izraelita purim ünnepén ,,a temérdek álarczos közt nemcsak izraeliták voltak, hanem a mi népünkből is néhány ifjú" (Zala-Somogyi Közlöny - a továbbiakban ZSK - 1863. 03. 10.).

A munka világa ugyancsak messzemenóen befolyásolta, hogy ki hogyan vehetett részt a nyilvános életben. A megye markánsan és hagyományosan mezőgazdasági terület volt: lakói között a birtokosok és bérlők 53.000 fős, illetve az őstermelésben foglalkoztatott munkások 64.000 fős tömege volt a domináns. Birtokosok és munkások között - a nyilvános élethez való viszonyukat tekintve - alapvető határvonalat jelentett, hogy míg a birtokaik jövedelméból élők számára a kulturális vagy társas életben való részvételt alapvetôen a városi báli szezon és a vidéken vagy fürdőhelyen töltött időszak váltakozása határozta meg, addig a munkások számára a mezőgazdasági munkák időhöz kötöttsége volt a döntő. A mezőgazdasági idényben a munkásoknak nem volt lehetôségük a nyilvános életben való aktív részvételre. Ahogyan a korabeli lap megfogalmazta: „A vásár napjai félünnepet képeznek a parasztgazda naptárában.” (ZSK, 1862. 08. 20.) Ehelyett a gazdálkodó életvitelhez a társas életnek rá jellemző, speciális formái kapcsolódtak: például a termények betakarítása, feldolgozása során zajló közös tevékenységek (az aratási ünnep,a szüret, az asszonyok, gyerekek közösen végzett munkái stb.).

Mindazonáltal a hagyományos nyilvános életben nagy jelentősége volt a profán ünnepeknek. Báli időszakban a megye városaiban egymást érték a mulatságok. Az 1863 januárjában például a „,zalai nemes ifjúság rendezett tánczvigalmat Sümegen, 
(...) Nagykanizsán a kereskedelmi kaszinóegylet” (ZSK, 1863. 01. 10.). Ugyancsak januárban mulatságot tartottak a kanizsai nagy kaszinóban és a polgári egyletben (ZSK, 1863. 01. 20.), valamint Csáktornyán is (ZSK, 1863. 02. 01.).

Tézisem szerint a társas életben a forradalmat követôen is továbbéltek a társadalmi nagycsoportok rendi kötöttségei. Ezt az állítást a báli események vizsgálata megerősíti. A magát „zalai ifjakként” megnevező társaság évről-évre megrendezte táncos mulatságát. De vajon kik voltak az említett ,ifjak”, és kik vehettek részt az ő mulatságaikon? A Zala-Somogyi Közlöny az 1864-es báli szezon apropóján éppen ezt a kérdést firtatta. Ahogy a lap Bukógáti nevú szerzóje írja, a „zalai ifjak” nevéből nem derül ki, hogy pontosan kiket is takar: a birtokos, az iparos, a kereskedő, esetleg a földmúves ifjakat? Akárkikről legyen is szó, „legutóbb e névvel olyan pikniket rendeztek, ahonnan ki volt zárva zsidó, prokátor, purger" (ZSK, 1864. 01. 20.). Más forrásokból - a fóispáni helytartó levéltári irataiból - egyértelmúen kiderül, hogy az ifjak a megye fóúri sarjai és a zalai nemesek voltak, akik a belépti díjak árának magasra emelését eszközül használva eleve elzárkóztak a társadalmi keveredéstől. Másrészről ugyanakkor a helyi elit szívesen mulatott a maga zártkörû́ rendezvényein kívül is. Erre adott lehetôséget az 1864 báli szezonjában először megrendezett „,cseléd tánczvigalom,” amelyen cselédek és uraik együtt vehettek részt. A mulatság azonban nem volt maradéktalanul sikeres, ugyanis: „számosan jelentek meg cselédek és mívelt urak, kik egymással kedvesen mulattak volna, ha nem jelennek meg a mívelt osztályból sokan, melák, buldog, kopó, vizsla, pincs-ebekkel, melyek az álarczosokat hangos ugatással vevék üldözőbe" (ZSK, 1864. 02. 10.). Hogy az urak szándékos heccéről vagy csupán véletlen balszerencséról volt szó, arról a források hallgatnak. Akárhogyan is, a cselédvigalom mindenképpen formabontó volt abban a tekintetben, hogy a hagyományos társadalmi válaszvonalak fellazítását célozta (hiszen cselédek és urak közös mulatsága korábban még csak ötlet szintjén sem merült föl). A végső értékeléshez azonban érdemes idézni a megyei lap kommentátorának ide vonatkozó megjegyzését, miszerint: „Zugolódott a cselédosztály [mármint az urak kutyáinak megjelenése miatt, K. Zs.], de mit sem tehetett, mert az ur szavára a szolgának hallgatni kell” (uo.).

1864-ben járunk, tehát egy évtizeddel azután, hogy Mocsáry Lajos papírra vetette a magyar társas életről rajzolt korképét (kórképét). De még az eltelt egy évtized után is helytállóak az ő szavai: „kasztok, osztályok, kiváltságok a társaságban folyvást léteznek százados elő́itéleteikkel... Sokkal többen vannak kétségtelenül, kik magokat azokon tökéletesen túlteszik, de a nagy többség még csak némi részben, közte sok tán mit sem engedett” (Mocsáry 1855: 18.).

A 19. század közepén lezajló polgári forradalom révén megkezdődött a hagyományos társadalmi választóvonalak, határok lebontása. Ezt a folyamatot erősítette a polgári forradalmakkal egy időben zajló gazdasági forradalom, amely átalakította a termelés rendjét. De nemcsak termelését, hanem - ahogyan arra az elsők között Niel McKendrik és szerzőtársai felhívták a figyelmet - a fogyasztásét is. A 18. századi Angliában a városok gazdaságának fellendülése és ezzel párhuzamosan egy modern értelemben felfogható fogyasztói réteg megszületése figyelhetô meg. Ezt a folyama- 
tot nevezi az angol történetírás „fogyasztói forradalomnak” (consumer revolution) (McKendrik és társai 1982). ${ }^{1}$ Az ipari forradalom eredményeképp megnövekedett termelés a fogyasztói javak piacának minden területén éreztette hatását, így a gazdasági változások hatására a szabadidő eltöltésének is új formái jelentek meg. Ezek azonban nem egyformán voltak elérhetőek a társadalom csoportjai számára, sốt jószerével elzártak maradtak mindazok elől, akik nem rendelkeztek megfelelő jövedelemmel vagy éppen az új jelenségek befogadásához szükséges kulturális háttérrel. A „fogyasztói forradalom" messzemenó hatással volt a társadalom kulturális tagolódására. A polgárosodás, a kulturálódás értelmében vett „civilizáció” és a társadalmi távolságtartás (social distancing) ugyanis kéz a kézben jártak (Borsay 1989: 286.). Ez nem mást jelent, mint hogy miközben egyfelől a hagyományos társadalmi-kulturális választóvonalak (a vallás, az öröklött státusz vagy éppen a foglalkozási struktúrában elfoglalt hely) veszítettek erejükből, ugyanakkor a korábbiakban nem ismert jelentőségre tett szert a fogyasztásban, különösen pedig a kulturális javak fogyasztásában betöltött pozíció. Az ebből fakadó kulturális határokat nevezem „modernnek.”

\section{Modern kulturális választóvonalak}

A 19. század közepére Magyarországon is egyre inkább megfigyelhető, hogy a társas élet eddig bemutatott hagyományos formái mellett újak is megjelennek. Valószínúleg túlzás volna Magyarországon „forradalomról” beszélni a fogyasztás terén, annyi mégis elmondható, hogy nálunk is fellendülés kezdődött, elsősorban a városokba koncentrálódva. Ez több módon is megmutatkozott: a városok népességének növekedésében, a városi épített környezet megváltozásában (parkosítás, sétaterek nyitása, korzók építése), a városi gazdaság jellegzetes mintázatainak átalakulásában - például a tercier szektor megerősödésében. És mindezek mellett elsősorban abban, hogy kiszélesedett a szabadidő eltöltésére kínálkozó lehetőségek és formák köre, és a megsokasodott lehetőségek mind szélesebb közönség számára váltak elérhetôvé.

A továbbiakban a nyilvános társas életnek ezeket az új típusú fórumait veszem sorra röviden, miközben igyekszem megmutatni a fogyasztó kultúra magyarországi kibontakozásának sajátosságait is. E sajátosságok közül a legmarkánsabb az, hogy míg nyugaton a „fogyasztói forradalom” egyik legfőbb vívmánya a társadalmi osztályok közötti kulturális határvonalak fellazítása, addig nálunk a fogyasztói kultúra elterjedése során a társadalmi csoportok közötti hagyományos határok nem - vagy csak részben - omlottak le.

1 A szerzők azt állítják, hogy a 18. század angol társadalom fogyasztói forradalmat élt át; az egy főre eső fogyasztás ugrásszerúen megnőtt az arisztokrácián kívüli társadalmi rétegekben is. ,„.. [a] 18. század második fele a szerzés és költés olyan lüktetésének,... a termelési és értékesítési technikák olyan robbanásszerú fejlődésének lett szemtanúja, melynek következtében a társadalom különféle rétegei korábban nem látott mértékben élvezhették a vásárlás örömeit...” (McKendrick, Brewer, Plumb 1982: 9; a fordítást Zentai Violetta: A fogyasztás kultúrája és a történelem. címú cikkéből idéztem. Lásd: Replika 1996. [21-22.] 139-159.). 
Az új típusú közönségprogramok közül Zalában a leggyakoribb a zenészek és a táncmúvészek fellépése volt. Nagykanizsán például szinte minden hónapra jutott egy-egy hegedû-2 ${ }^{2}$ fuvola- ${ }^{3}$ vagy énekmúvészi előadás. A híresebb fellépők, mint például Hollósy Kornélia4 ${ }^{4}$, ,a körülfekvő megyék távol vidékeiről is” (ZSK, 1863. 05. 20.) összegyújtötték a közönséget, mások esetleg csak a városokból vagy a városokhoz közel fekvő vidékről csalogatták az érdeklődőket.

A fellépők számának megszaporodásával párhuzamosan a kínálat differenciálódása is megindult. Amíg az említett Hollósy Kornélia vidéki turnéi alkalmával az opera népszerúsítésén munkálkodott, és músoraival elsősorban a múvelt, elit közönséget szólította meg, addig a nyaranta zsúfolásig telt kerthelyiségekben a szórakozva múvelődni vágyó közép- és alsóbb rétegekből kikerülő közönség találta meg a neki szóló programokat. A lehetőségek és a helyszínek gyarapodása elválasztotta egymástól a különböző társadalmi rétegeket. A helyi múkedvelő elit közönségnek szervezett múvészeti estélyeken a városlakó nemesség és hivatalnokértelmiség múlatta az idejét, miközben a városok és a környékbeli falvak mulatói, mulatókertjei az alsóbb rétegek spontán találkozásának, mulatozásának nyitottak teret. „A szép időt már élvezni kezdi a közönség a mulató kertekben, melyek egyikében minden vasárnap egy állatot lehet nyerni." - szólt például a Zala-Somogyi Közlöny egyik rövid híradása (ZSK, 1863. 04. 20.); ilyen mulatókertben a megyei nemesek azonban sosem fordultak meg.

Megjelentek egészen újfajta látnivalók is, de ezek ugyancsak differenciáltan jutottak az egyes társadalmi csoportokhoz. A modern technika nagy vívmánya volt a fényképezés. Az 1862-ben Nagykanizsára látogató „,körmendi gyógyszerész - mint fényképész" (ZSK, 1862. 07. 01.) szolgáltatásai azonban - a magasan szabott árak miatt - csupán egy szúkebb kör számára voltak elérhetőek. Ha fényképet nem is csináltathatott magáról bárki, a fotómúvészet eredményei nagyobb közönség számára is elérhetôvé váltak, amikor a városi vendéglőben egy másik fotómúvész, „természethú photographiai látványosságot”, vagyis 300 fotót állított ki (ZSK, 1863. 10. 10.). Ugyancsak populáris esemény, a hagyományos állatvásárok mintájára megszervezett látványosság volt az a ,nagyszerú állatsereglet..., mely közt egy nagy oroszlán mutogattatik” (ZSK, 1863. 08. 01), vagy a „,világhírú olasz herkules, akrobata és erômutatványai" (ZSK, 1864. 02. 10). A fizikai hatások és benyomások (erô, méret, bátorság) előtérbe helyezése a tradicionális vásári mutatványokhoz közelítették ezeket az újszerú látványosságokat is, így befogadhatóbbá, a megszokott kulturális keretek között értelmezhetővé téve őket az elit kultúrából továbbra is kirekedtek számára.

2 „Beckner Sarolta hegedúmúvésznő a Zöldfa szálloda termében” (ZSK, 1862. 06. 01.); Frank Ignác néphegedás előadása ugyanott 1863. márc. 28-án (ZSK, 1863. 04. 01.).

3 „A Doppel testvérek fuvolakoncertjén, Sipos Antal zongoramúvész is közremúködik a Zöldfa vendéglőben." (ZSK, 1862. 07. 20.)

4 Hollósy Kornélia (1827-1890), szoprán operaénekesnő, 1846-49 és 1854-1862 között a Nemzeti Színház tagja volt. A forradalom alatt és után számos jótékonysági akcióban vett részt, évi fizetésének három százalékát a honvédségnek és a Nemzeti Bank létrehozására ajánlotta. Széchenyi temetésén ő énekelte a Requiem szólóját, utolsó jelentős fellépésén pedig, a Bánk bán ősbemutatóján (1861-ben) Melinda szerepét énekelte. 
Az 1840-es évek megalapozó időszaka után a színjátszás is a forradalom utáni időszakban teljesedett ki. A megyében csak Balatonfüreden volt színház, de annak ellenére, hogy sem Zalaegerszegnek, sem Nagykanizsának nem volt állandó színháza vagy koncertterme, ezekben a városokban is számos színtársulat megfordult. A színielőadásokra - a más nyilvános eseményekhez hasonlóan - kirendelt hatósági biztosi beszámolókból ismeretes azonban az is, hogy a közönség legnagyobbrészt a városi középrétegekből (polgárok, tanárok, mérnökök) került ki, és az újfajta kulturális élmény sem a magasabb rangúakat, sem pedig az alacsonyabb társadalmi helyzetúeket nem igazán érte el. Ugyancsak a középréteg jelentette a megyei fürdőhelyek - elsôsorban Füred - legtipikusabb közönségét is. A reformkor óta népszerú fürdőhelyen a korszakban indult meg a fürdőzéshez kapcsolódó többletszolgáltatások körének kiszélesedése. 1861 és 1863 között önálló fürdőlap jelent meg, megnyitott a település kölcsönkönyvtára is, sôt egy lövölde is a vendégek rendelkezésére állt, és rendszeressé váltak az évente megrendezett Anna-bálok (Katona 2002: 69.).. Mindezek mellett megkezdődtek a fürdőhöz kapcsolódó nagyberuházások, amelyeket - mint a fürdőhely kutatója írja - ebben a korszakban már „elsôsorban nem a szükség, hanem az előrelépés szándéka diktált" (uo.: 70.). Mindezek az újdonságok valóban arra utalnak, hogy az 1860-as években fogyasztói fellendülés (ha nem is forradalom) kezdődött a balatoni fürdőhelyen. Ugyanakkor megváltozott a fürdővendégek társadalmi összetétele. Az itt megforduló vendégek között a reformkorban a „mértékadó csoport” a környékbeli vármegyék hivatalviselő és birtokos köznemessége volt (Hudi 1989). Húsz évvel később „a reformkorra jellemző patriarchális fürdőéletet lassan felváltotta a polgári értelemben vett szabadidőhöz kötődő, tudatos nyaralási-szórakozási igény" (Katona 2002: 56.). Eddigre az arisztokrata vendégek száma a töredékére csökkent a korábbinak, „,a legtöbb fürdővendég a kereskedők közül került ki”, rajtuk kívül pedig továbbra is ,a birtokos és többségében megyei hivatalt viselő nemesség, valamint az értelmiség különböző rétegeinek képviselői időztek Füreden nagyobb számban” (Katona 2009: 198.).. Csakhogy ez a középosztály belülrôl igencsak tagolt volt - ahogyan erre a megyei közlöny tudósítója, a füredi és keszthelyi idény hangulatáról egyébként meglehetősen lehangoló képet festő beszámolóiban nyomatékosan fel is hívta a figyelmet. „Egyébként Füreden - szól az egyik ilyen beszámoló - a közönség nagy részben dandykből s zsidókból áll; s az utóbbiak nem pusztán henyélő mulatók. A cotteriák [értsd: kotériák, azaz társaságok, klikkek] gyönyörúen díszlenek. Kedély, fesztelenség, mint még annyi pauvre [értsd: szegény, szegénységre jellemző] tulajdonságok, innét számúzve. Pompás toilettek, szép fogatok a szegény filisztert folytonos feszültségben tartják. Lövöldözések, szelidebb párbajok, regatták a programhoz tartoznak. Bál esténkint, de csak a »kék vér« számára” (ZSK, 1863. 09. 20.). Hiába csökkent a vendégek között az arisztokraták száma, a szépreményú „,nemesifjak” és a - vélhetóen nagyobb részben a zsidók közül kikerülő - kereskedők csoportjainak elkülönülése rányomta a bélyegét a fürdőhelyek mindennapjaira (errôl lásd még Katona 2002: 60-63.). A fürdőhelyeken az 1860-as években mindezek szerint (még) nem történt meg a hagyományos társadalmi válaszfalak lebomlása, társadalmi-kulturális értelemben nem teljesedett ki a polgárivá válás. 


\section{Összegzés}

A nyilvános élet intézményesített formát nem öltô fórumainak hagyományos és modern típusai egy idóben, egymás mellett múködtek. Jellegzetesen eltért azonban az e fórumokon résztvevốk köre. Amíg a megye vidéki, azaz városokon kívüli részén még a század második harmadában is a nyilvánosság hagyományos fórumai voltak az uralkodók, addig a városokban az egymással összekapcsolódó gazdasági és társadalmi változások hatására a vizsgált korszakban a nyilvánosságnak mind több újszerú fóruma is megjelent. Részben még Zala megye partikuláris példáján is igazolva látom azt a megállapítást, amely szerint az ipari fellendüléssel egy időben, azzal összefüggésben megváltozott a fogyasztói, kulturális fogyasztói magatartás is, ami a szabadidó eltöltésének (és ezzel együtt a nyilvános életnek) új és változatos formáit hívta életre. Amíg azonban a „fogyasztói forradalomról” szóló nyugati szakirodalom szerint e folyamat egyik lényeges társadalmi hozadéka a társadalmi osztályok közötti átmenet könnyebbé válása, addig - legalábbis a talált források tükrében Zala esetében úgy túnik - nálunk ezek az új fórumok is csak kevéssé tudtak hozzájárulni bizonyos hagyományos, merev társadalmi határvonalak (mindenekelőtt például a keresztények és izraeliták, vagy a városi és vidéki lakosság közötti választóvonalak) bomlásnak indulásához.

\section{Hivatkozott irodalom}

Borsay, Peter (1989): The English Urban Renaissance. Culture and Society in the Provincial Town, 1660-1770. Oxford, Calendron Press.

HUDI JózSEF (1989): A balatoni fürdókultúra a reformkorban. In Bilkei Irén (szerk.): Közlemények Zala megye közgyújiteményeinek kutatásaiból, 1988. (Zalai Gyújtemény 28.) Zalaegerszeg, Zala Megyei Levéltár, 109-135.

Katona Csaba (2002): Füred és vendégei. Egy fürdőhely és „társadalma” az 18401860-as években. Korall (7-8), 56-77.

Katona Csaba (2009): A balatoni nyár - anno 1861. In Paksy Zoltán (szerk.): Zalai történeti tanulmányok, 2009. (Zalai Gyújtemény 67.) Zalaegerszeg, Zala Megyei Levéltár, 191-230.

McKendrick, Niel-Brewer, John-Plumb, J. H. (1982): The Birth of a Consumer Society: The Commercialization of Eighteenth-Century England. London, Europa Publications.

MocsÁry Lajos (1855): A magyar társasélet. Pest, Müller. 